\title{
From unresponsive wakefulness to minimally conscious PLUS and functional locked-in syndromes: recent advances in our understanding of disorders of consciousness
}

\author{
Marie-Aurélie Bruno $\cdot$ Audrey Vanhaudenhuyse • \\ Aurore Thibaut • Gustave Moonen • \\ Steven Laureys
}

Received: 12 May 2011/Revised: 16 May 2011/Accepted: 18 May 2011

(C) Springer-Verlag 2011

\begin{abstract}
Functional neuroimaging and electrophysiology studies are changing our understanding of patients with coma and related states. Some severely brain damaged patients may show residual cortical processing in the absence of behavioural signs of consciousness. Given these new findings, the diagnostic errors and their potential effects on treatment as well as concerns regarding the negative associations intrinsic to the term vegetative state, the European Task Force on Disorders of Consciousness has recently proposed the more neutral and descriptive term unresponsive wakefulness syndrome. When vegetative/unresponsive patients show minimal signs of consciousness but are unable to reliably communicate the term minimally responsive or minimally conscious state (MCS) is used. MCS was recently subcategorized based on the complexity of patients' behaviours: MCS + describes highlevel behavioural responses (i.e., command following, intelligible verbalizations or non-functional communication) and MCS - describes low-level behavioural responses (i.e., visual pursuit, localization of noxious stimulation or contingent behaviour such as appropriate smiling or crying to emotional stimuli). Finally, patients who show nonbehavioural evidence of consciousness or communication only measurable via para-clinical testing (i.e., functional MRI, positron emission tomography, EEG or evoked potentials) can be considered to be in a functional locked-in
\end{abstract}

M.-A. Bruno and A. Vanhaudenhuyse have contributed equally.

M.-A. Bruno - A. Vanhaudenhuyse - A. Thibaut - G. Moonen ·

S. Laureys $(\bowtie)$

Coma Science Group, Neurology Department

and Cyclotron Research Centre, University Hospital

and University of Liège, Liège, Belgium

e-mail: coma@chu.ulg.ac.be

URL: http://www.coma.ulg.ac.be syndrome. An improved assessment of brain function in coma and related states is not only changing nosology and medical care but also offers a better-documented diagnosis and prognosis and helps to further identify the neural correlates of human consciousness.

Keywords Coma $\cdot$ Vegetative state $\cdot$ Minimally conscious state . Locked-in syndrome $\cdot$ Consciousness · Unresponsive wakefulness syndrome

\section{Introduction}

We will here discuss the recent advances in our understanding of disorders of consciousness and focus on their clinical consequences in terms of patients' diagnosis. This new knowledge also permits us to better identify of the underlying mechanisms of these disorders and redefine our nosological distinctions needed for accurate neurological management. Severely brain damaged patients continue to represent major ethical challenges regarding end-of-life issues (for a recent European survey, see [1]). This was dramatically illustrated in Italy by the case of Eluana Englaro, a 36-year-old woman who remained unconscious for 17 years after a traumatic brain injury [2]. The widespread use of the artificial respirator in the 1960s led to the redefinition of death based on neurological criteria (i.e., brain death or irreversible coma with absent brainstem reflexes [3]) and to the identification of pseudocoma (i.e., locked-in syndrome [4]). In the 1970s patients who awakened from coma (meaning they open their eyes spontaneously or after stimulation) but remained without communication or behavioural signs of consciousness were said to be in a vegetative state (VS) [5] (previously called apallic syndrome or coma vigil). Vegetative was chosen to 
refer to the preserved vegetative (autonomous) nervous functioning in these patients (e.g., sleep-wake rhythm, respiration, digestion and thermoregulation). The term persistent was added to denote that the condition remained for more than 1 month after insult. In 1994, a retrospective study of all published cases permitted to propose temporal boundaries for the irreversibility of this syndrome, hence proposing the term permanent vegetative state [6] (unfortunately persistent and permanent VS share the common abbreviation of PVS leading to unwarranted confusion). It is to these cases that end-of-life issues of withholding and withdrawal of life sustaining treatment (i.e., artificial hydration and nutrition) are related [2, 8]. In 2002, the operational criteria for minimally conscious state (initially called minimally responsive state) were published and recommended (albeit not yet endorsed) by the American Academy of Neurology, separating non-communicative vegetative patients from non-communicative patients showing minimal behavioural signs of consciousness [9]. Emergence from the minimally conscious state was defined by functional communication or functional use of objects.

\section{Time for a new nosology of disorders of consciousness?}

Over the last three decades, an increasing number of clinicians remained uncomfortable when referring to patients as vegetative (e.g., [10]), resulting in a number of papers reiterating the intellectual justification of the origins and choice of the term [5]. This resulted in last years' introduction by the European Task Force on Disorders of Consciousness of the term unresponsive wakefulness syndrome [11]. Their reasons for calling these patients unresponsive rather than vegetative were multiple. First, the word vegetative has an unintended, albeit persistent, negative connotation. The Oxford English Dictionary defines vegetative as "an organic body capable of growth and development but devoid of sensation and thought" and to vegetate as to "live a merely physical life devoid of intellectual activity or social intercourse". The notion of a vegetative nervous system dates to the 1800 s when the nervous system was divided into animalic (i.e., related to sensory perception and voluntary motor responses) and vegetative parts (i.e., assuring nutritional functions). However, for many laypersons this notion has a very pejorative undertone and incorrectly refers to these patients as being "vegetable-like". A number of highly publicised patients illustrate this point. Julia Tavalaro survived a brain trauma and was transferred to a tertiary care centre where she was called the vegetable for over 6 years, although she was conscious and sensate. She later wrote her memoirs in Look Up for Yes [12]. A recent Google search with "Terri Schiavo" and "vegetable" returned 410,000 hits, and
"Eluana Englaro" and "vegetable" gave 31,700 hits (performed April 25, 2011). A number of authors and social, political and religious groups have, hence, felt the need to emphasize these patients' rights to be fully regarded as human beings (e.g., [13, 14]). Second, vegetative state for many physicians implies cortical death and persistency from the moment of diagnosis. This started when the New York Times (August 5, 1968) announced the Harvard criteria for brain death. In the accompanying editorial, it read: "As old as medicine is the question of what to do about the human vegetable... Sometimes these living corpses have survived for years... It is such cases, as well as the need for organs to be transplanted that the Harvard faculty committee had in mind in urging that death be redefined as irreversible coma" [3]. The case of Terri Schiavo also illustrates this point, as commentators have inaccurately referred to her condition as brain death or neocortical death [15]. However, patients with disorders of consciousness are not uniformly hopeless [16, 17] and increasing evidence from clinical [18] and neuroimaging studies (e.g., [19, 20]) have shown that clinicians need to be cautious about making strong claims concerning allegedly vegetative patients' consciousness. Clinical practice shows that once stamped with the diagnosis vegetative state it frequently is difficult to change the label, and the first signs of recovery of consciousness are too often missed. Terry Wallis, who made the headlines when starting to speak after being considered vegetative for 19 years post-trauma, well illustrates this point [21]. Subsequent analysis of his medical files showed he actually was minimally conscious for all those years (albeit lacking proper rehabilitation) [22]. Hence, for over 35 years the medical community has been unsuccessful in changing the pejorative image associated with the words vegetative, and given the diagnostic errors and their potential effect on the treatment and care for these patients, physicians are now offered a more neutral and descriptive alternative: unresponsive wakefulness syndrome. It refers to these patients showing a number of clinical signs (i.e., syndrome) of unresponsiveness (i.e., without response to commands) in the presence of wakefulness (i.e., showing eye opening).

Some vegetative/unresponsive patients will irreversibly remain in this condition but many may evolve to a minimally responsive or minimally conscious state (MCS) [23]. Since its formal definition nearly 10 years ago [9], a number of authors have questioned the usefulness of differentiating vegetative/unresponsive from minimally responsive patients considering both patient groups as hopelessly brain damaged [24]. Recent studies have demonstrated that it is important to disentangle both clinical entities as functional neuroimaging have shown differences in residual cerebral processing and hence, conscious perception (e.g., [20, 2527]), as well as differences in outcome (e.g., [28, 29]). 
However, controlled prospective studies on prognosis (and on treatment) in large, well-described cohorts of patients with disorders of consciousness, permitting evidence-based decision-making are still awaited. It has been recently proposed that the World Health Organization would recognize MCS in its International Statistical Classification of Diseases (9th Revision, Clinical Modification; ICD-9-CM) diagnosis codes and related Current Procedural Terminology (CPT) medical procedure codes (maintained by the American Medical Association) [30]. ICD codes classify symptoms, diseases, or injuries into categories with unique codes permitting standardized epidemiological, morbidity and mortality studies and reimbursement and medical decision-making. The current lack of a unique code for MCS may encumber scientific studies, medical information retrieval, demographic and international analyses on prevalence and prognosis for disorders of consciousness. In a next step, we have proposed to subcategorize the clinically heterogeneous MCS entity into minimally conscious PLUS (MCS+) and MINUS (MCS-) based on the level of complexity of observed behavioural responses [31]. MCS+ was defined by the presence of (a) command following, (b) intelligible verbalization or (c) gestural or verbal yes/no responses. In contrast, MCS- patients only show minimal levels of behavioural interaction characterized by the presence of non-reflex movements such as: (a) orientation of noxious stimuli, (b) pursuit eye movements that occur in direct response to moving or salient stimuli, (c) movements or affective behaviors that occur appropriately in relation to relevant environmental stimuli (such as appropriate smiling or crying in response to the linguistic or visual content of emotional, but not to neutral, topics or stimuli, vocalizations or gestures that occur in direct response to the linguistic content of questions, reaching for objects that demonstrates a clear relationship between object location and direction of reach, touching or holding objects in a manner that accommodates the size and shape of the object). Future outcome studies should assess possible differences in prognosis, and neuroimaging studies could demonstrate the predicted differences in cognitive capacities and underlying functional neuroanatomy between MCS+ and MCSsubclasses.

Figure 1 shows a simplified flow chart summarising the possible transitions from coma to brain death [3], classical locked-in syndrome (i.e., quadriplegia and anartria with eye-coded communication typically following brainstem stroke [4]) or vegetative state (now also called unresponsive wakefulness [11]). As said, from the latter condition, some patients may recover non-reflex movements (i.e., minimally conscious state minus; MCS-) and some may later recover more complex behaviours such as a response to commands (i.e., minimally conscious state plus; $\mathrm{MCS}+$ ) [31]. The upper boundary of MCS is defined by the recovery of communication or functional use of objects [9]. Note that not all patients will go through all transitions; some may rapidly show good recovery while others may remain in a chronic disorder of consciousness for months or years. Patients who remain vegetative/unresponsive for over 12 months following a traumatic brain injury and 3 months following non-traumatic aetiology were considered to have very small if any chance of recovery [6] but more recent studies have been challenging these temporal boundaries of irreversibility (e.g., [7]). Whereas the temporal boundaries of irreversibility have been proposed for vegetative/unresponsive patients, at present no such data exist for MCS where chances of recovery are known to be
Fig. 1 Proposed nosology of the diagnostic entities than can be encountered following coma, based on clinical behavioural evaluation (in white) and based on novel para-clinical functional neuroimaging studies (in grey)—see text for details

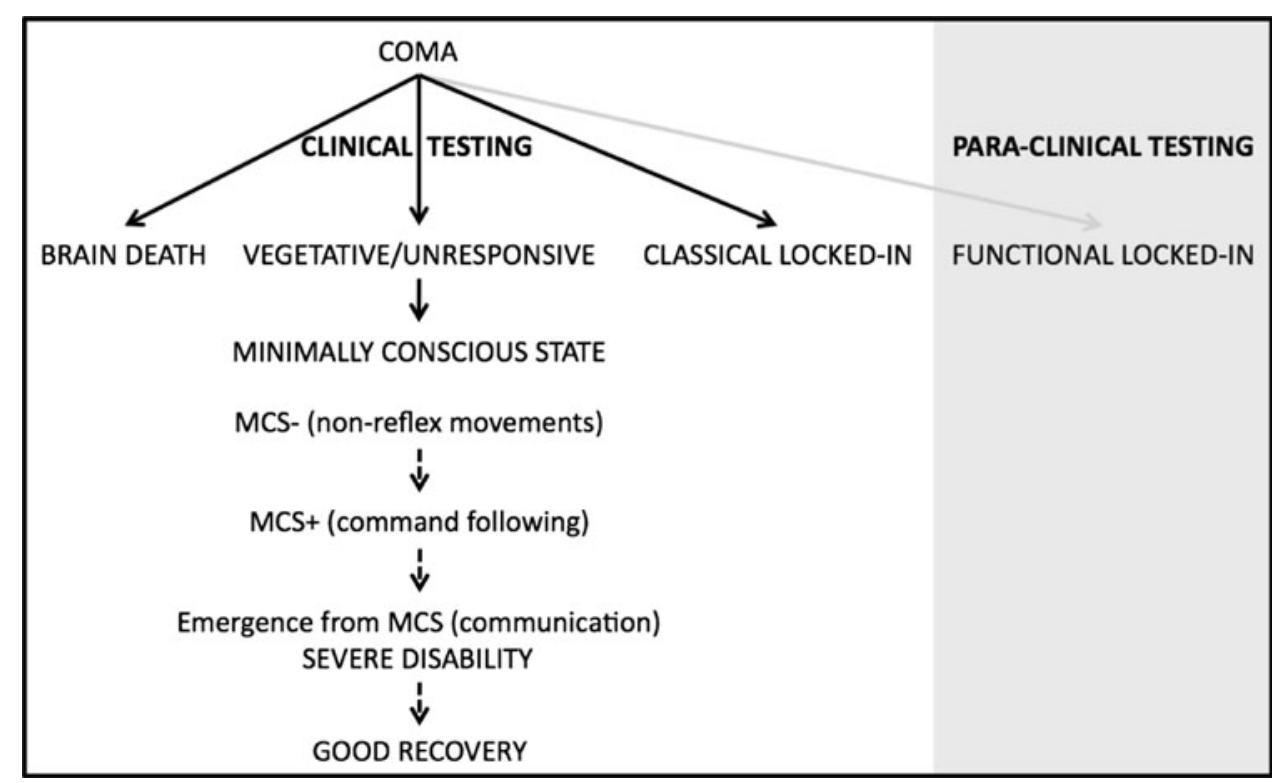


better [28]. As we will see, the term functional locked-in syndrome could be proposed for patients with a dissociation between extreme behavioural motor dysfunction and the identified preserved higher cognitive functions only measurable by functional imaging techniques.

\section{Clinical bedside assessment using consciousness scales}

At present, clinical behavioural examinations permit one to identify the above-described nosological distinctions needed for accurate diagnosis and prognosis. How do we quantify consciousness at the bedside [32]? Consciousness is a multifaceted concept that can be reduced into two major dimensions: arousal (i.e., wakefulness or vigilance) and awareness (i.e., comprising all subjective perceptions, feelings and thoughts) [33]. Awareness, in turn, can be divided into awareness of the external world (i.e., sensory or perceptual awareness of the environment) and awareness of the internal world (i.e., stimulus-independent thoughts, mental imagery, inner speech, daydreaming or mind wandering) [34]. Clinically, arousal will simply be assessed by examining the presence of spontaneous or stimulus induced eye-opening and the presence of reproducible commandfollowing will be taken as proof of (external) awareness. Additionally, as previously discussed, the presence of spontaneous or induced non-reflex behaviours will be considered as evidence of (minimal) consciousness (MCS-). The bedside examination of consciousness in severely brain damaged patients often is very challenging because observed movements may be very small, inconsistent and easily exhausted, potentially leading to diagnostic errors. This issue is further complicated when patients have underlying deficits in the domain of verbal or non-verbal communication functions, such as aphasia, agnosia or apraxia [35, 36]. This problem was recently highlighted in a study showing that the clinical consensus diagnosis could be incorrect in more than $40 \%$ of patients considered to be vegetative [18]. Locked-in syndrome patients may also be mistakenly considered unconscious $[37,38]$. These studies should aid clinicians to use standardized validated behavioural scales of consciousness when making a diagnosis in these challenging patients. However, while consensus-based diagnostic guidelines for disorders of consciousness have been established [9], there are no procedural guidelines regarding bedside assessment.

In a recent milestone paper, the American Congress of Rehabilitation Medicine conducted a systematic, evidencebased review of behavioural assessment scales for disorders of consciousness and provided evidence-based recommendations for clinical use founded on content validity (i.e., enclosing diagnostic criteria), reliability, diagnostic validity, and ability to predict functional outcomes [39].
Expert consensus-based evaluations of the included consciousness scales are shown in Table 1. Interestingly, the diagnostic validity (i.e., the scale's ability to establish an accurate diagnosis compared with the true diagnosis as measured by a reference standard) was unproven for all behavioural scales, stressing the need for future studies. In addition to the diagnostic value of these consciousness scales, the authors also considered their usefulness in predicting patients' recovery of consciousness or function. Outcome measures varied across the different reviewed studies. The majority employed the Glasgow Outcome Scale [40] to define the degree of recovery of severely brain damaged patients, while others used the Rankin Scale Score [41] or simply used a non standardized assessment. Of interest is that most studies predicted disability levels with death included as an outcome. The FOUR scale, administered $24 \mathrm{~h}$ or sooner post-insult, was shown to be predictive of good recovery versus disability or death at 1 month post-insult, while the GLS assessment $24 \mathrm{~h}$ or less post-insult was possibly predictive of good recovery or moderate disability versus severe disability or permanent unresponsive/vegetative state or death at 6 months postinsult, in line with a recent study performed in the acute setting [42]. In conclusion, it is recommended to use the Coma Recovery Scale-Revised (CRS-R summarized in Table 2) rather than to perform an unstructured clinical assessment [19] or coma scale such as the Glasgow Coma Scale [44] when diagnosing disorders of consciousness after coma.

\section{Para-clinical neuroimaging assessment independent of motor responses}

It is important to stress that all the previously discussed behavioural scales make inferences about patients' (un)consciousness based on (the absence of) motor responsiveness. In the past 15 years, functional neuroimaging [e.g., positron emission tomography and functional MRI (fMRI)] and cognitive evoked potential studies have offered the possibility to measure directly and non-invasively severely brain damaged patients' brain activity at rest and during external activation (for review, see [58]). More recently, however, these techniques have been developed aiming to detect neural (motor-independent) command following. A collaborative study between the Cambridge and Liège groups [59] showed that a clinically vegetative patient could repeatedly and for prolonged periods of time perform mental imagery tasks, as shown by fMRI. When the patient was asked to imagine playing tennis, robust activation was observed in the supplementary motor area. The instruction to imagine moving around in her house resulted in parahippocampal activation. These 
Table 1 Summary of the American Congress of Rehabilitation Medicine evidence-based review of behavioural assessment scales for disorders of consciousness [39]

\begin{tabular}{|c|c|c|c|c|c|c|c|c|}
\hline Scale & $\begin{array}{l}\text { Free } \\
\text { access }\end{array}$ & $\begin{array}{l}\text { Guidelines of } \\
\text { administration } \\
\& \text { scoring } \\
\text { procedures }\end{array}$ & $\begin{array}{l}\text { Content validity } \\
\text { (i.e., enclosing } \\
\text { diagnostic } \\
\text { criteria) }\end{array}$ & $\begin{array}{l}\text { Internal } \\
\text { consistency }\end{array}$ & $\begin{array}{l}\text { Inter-rater } \\
\text { reliability }\end{array}$ & $\begin{array}{l}\text { Test- } \\
\text { retest } \\
\text { reliability }\end{array}$ & $\begin{array}{l}\text { Diagnostic } \\
\text { validity }\end{array}$ & $\begin{array}{l}\text { Outcome } \\
\text { prediction }\end{array}$ \\
\hline $\begin{array}{l}\text { Coma Recovery Scale- } \\
\text { Revised (CRS-R, [45]) }\end{array}$ & Yes & Present & Excellent & Good & Good & Excellent & Unproven & Unproven \\
\hline $\begin{array}{l}\text { Sensory Stimulation } \\
\text { Assessment Measure } \\
\text { (SSAM, [46]) }\end{array}$ & Yes & Present & Good & Unproven & Unproven & Unproven & Unproven & Unproven \\
\hline $\begin{array}{l}\text { Wessex Head Injury } \\
\text { Matrix (WHIM, [47]) }\end{array}$ & No & Present & Good & Unproven & Unproven & Unproven & Unproven & Unproven \\
\hline $\begin{array}{l}\text { Western Neuro Sensory } \\
\text { Stimulation Profile } \\
\text { (WNSSP, 48]) }\end{array}$ & Yes & Present & Good & Excellent & Unproven & Unproven & Unproven & Unproven \\
\hline $\begin{array}{l}\text { Sensory Modality } \\
\text { Assessment and } \\
\text { Rehabilitation } \\
\text { Technique } \\
\text { (SMART, [49]) }\end{array}$ & No & Present & Good & NA & Excellent & Excellent & Unproven & Unproven \\
\hline $\begin{array}{l}\text { Disorders of } \\
\text { Consciousness } \\
\text { (DOC, }[50])\end{array}$ & Yes & Present & Acceptable & Good & Unproven & Unproven & Unproven & Unproven \\
\hline $\begin{array}{l}\text { Coma Near Coma } \\
\text { (CNC, [51]) }\end{array}$ & Yes & Present & Acceptable & Unacceptable & Unproven & Unproven & Unproven & Unproven \\
\hline $\begin{array}{l}\text { Full Outline of } \\
\text { Unresponsiveness } \\
\text { scale (FOUR, [52]) }\end{array}$ & Yes & Absent & Poor & Excellent & Good & Unproven & Unproven & Yes \\
\hline $\begin{array}{l}\text { Comprehensive Level } \\
\text { of Consciousness } \\
\text { Scale (CLOCS, [53]) }\end{array}$ & Yes & Absent & Acceptable & Good & Unproven & Unproven & Unproven & Unproven \\
\hline $\begin{array}{l}\text { Innsbruck Coma Scale } \\
\text { (INNS, [54]) }\end{array}$ & Yes & Absent & Poor & Acceptable & Unproven & Unproven & Unproven & No \\
\hline $\begin{array}{l}\text { Glasgow Liège Scale } \\
\text { (GLS, [55]) }\end{array}$ & Yes & Absent & Poor & Unproven & Unacceptable & Unproven & Unproven & Yes \\
\hline $\begin{array}{l}\text { Loewenstein } \\
\text { Communication Scale } \\
\text { (LOEW, [56]) }\end{array}$ & Yes & Absent & Acceptable & Unproven & Excellent & Unproven & Unproven & Unproven \\
\hline $\begin{array}{l}\text { Reaction Level Scale } \\
\text { (RLS85, [57]) }\end{array}$ & Yes & Absent & Acceptable & Unproven & Unproven & Unproven & Unproven & Unproven \\
\hline
\end{tabular}

specific activations patterns were not different from those previously observed in a cohort of healthy volunteers [60]. Since this case report, similar active or command following paradigms have been tested in severely brain damaged patients with different technologies such as fMRI, event related potentials or electromyography. In a next step, Monti and Vanhaudenhuyse et al. [19] employed the technique in a larger cohort of patients and adapted the methodology to establish fMRI-based communication. Out of the 54 patients enrolled in the study, five patients (all with traumatic brain injury) demonstrated willful modulation of brain activity (i.e., activating supplementary motor or parahippocampal areas, depending on the command). Four of these five patients were admitted to the hospital with a diagnosis of vegetative state (however, when assessed with the CRS-R, some behavioural indicators of consciousness could be detected in two cases). It should be stressed that the absence of command-related brain activation (i.e., a negative result) does not allow one to make strong claims about the absence of consciousness. Indeed, out of the 31 MCS patients studied, only one was able to show reliable fMRI activation in the expected brain areas (leading to a calculated sensitivity of only $3 \%$ ). Active fMRI paradigms in patients with disorders of consciousness have since been using various methodologies, asking patients to: "look at a screen and silently name the objects as they appear" (resulting in language network activation) [20]; "move the hand" (resulting in premotor cortex 
Table 2 Summary of Coma Recovery Scale-Revised administration and scoring guidelines [45]

\begin{tabular}{|c|c|c|}
\hline Item & Description & Number of observation \\
\hline \multicolumn{3}{|l|}{ Auditory Function Scale } \\
\hline 4-Consistent movement to command ${ }^{\mathrm{a}}$ & $\begin{array}{l}\text { Object-related eye or limbs movement or } \\
\text { non-object related commands }\end{array}$ & All 4 trials of 2 different commands $(8 / 8)$ \\
\hline 3-Reproducible movement to command ${ }^{\mathrm{a}}$ & $\begin{array}{l}\text { Object-related eye or limbs movement or } \\
\text { non-object related commands }\end{array}$ & $\begin{array}{l}3 / 4 \text { trials on any one of the object or non- } \\
\text { object related commands }\end{array}$ \\
\hline 2-Localization to sound & $\begin{array}{l}\text { Auditory stimulation (e.g. voice or noise) } \\
\text { from the right and the left side for } 5 \mathrm{~s} \text {. } \\
\text { Repeat the procedure } 2 \text { times on each } \\
\text { side. }\end{array}$ & $\begin{array}{l}\text { Head and/or eyes orient toward the } \\
\text { stimulus on both trials in at least one } \\
\text { direction. }\end{array}$ \\
\hline 1-Auditory startle & $\begin{array}{l}\text { Auditory stimulation directly above the } \\
\text { patient's head and out of view ( } 4 \text { trials). }\end{array}$ & $\begin{array}{l}\text { Eyelid flutter or blink following the } \\
\text { stimulus on at least } 2 \text { trials. }\end{array}$ \\
\hline 0 - None & Observe response to above method. & No response to any of the above. \\
\hline \multicolumn{3}{|l|}{ Visual Function Scale } \\
\hline 5-Object recognition ${ }^{\mathrm{a}}$ & $\begin{array}{l}\text { Object-related eye or limbs movement } \\
\text { commands }\end{array}$ & $3 / 4$ clearly discernible responses \\
\hline 4 -Object localization: reaching ${ }^{a}$ & $\begin{array}{l}\text { The patient is asked to touch an object } \\
\text { with his/her arm or leg, } 4 \text { trials ( } 2 \text { left, } 2 \\
\text { right presentations). }\end{array}$ & $\begin{array}{l}\text { Movement must occur in the correct } \\
\text { direction on } 3 / 4 \text { trials. }\end{array}$ \\
\hline 3-Pursuit eye movements ${ }^{\mathrm{a}}$ & $\begin{array}{l}\text { Move mirror } 45^{\circ} \text { to the right, left, upper } \\
\text { and lower directions. } 2 \text { trials in every } \\
\text { direction (manually open eyes if } \\
\text { necessary). }\end{array}$ & $\begin{array}{l}\text { Eyes must follow the mirror for } 45^{\circ} \\
\text { without loss of fixation on } 2 \text { occasions } \\
\text { in any direction. }\end{array}$ \\
\hline 2-Fixation ${ }^{b}$ & $\begin{array}{l}\text { Present a brightly coloured object in front } \\
\text { of the patient's face and then rapidly } \\
\text { move to upper, lower, right and left } \\
\text { visual fields for a total of } 4 \text { trials } \\
\text { (manually open eyes if necessary). }\end{array}$ & $\begin{array}{l}\text { Eyes change from initial fixation point } \\
\text { and then fixate on the new target } \\
\text { location for more than } 2 \mathrm{~s} \text {. At least } 2 \\
\text { fixations. }\end{array}$ \\
\hline 1 -Visual startle & $\begin{array}{l}\text { Quickly move a finger } 1 \text { inch in front of } \\
\text { the patient's eye, while avoiding contact } \\
\text { with the eyelashes or inadvertent } \\
\text { production of a breeze (manually open } \\
\text { eyes if necessary). } 4 \text { trials per eye. }\end{array}$ & $\begin{array}{l}\text { Blink promptly following presentation of } \\
\text { visual threat on at least } 2 \text { trials with } \\
\text { either eye. }\end{array}$ \\
\hline 0 - None & Observe response to above method. & No response to any of the above. \\
\hline \multicolumn{3}{|l|}{ Motor Function Scale } \\
\hline 6-Functional object use ${ }^{c}$ & $\begin{array}{l}\text { Place one object (comb) in the patient's } \\
\text { hand and instruct the patient to "Show } \\
\text { me how to use it". Repeat the same } \\
\text { instruction with a second object. } 2 \text { trials } \\
\text { for each object. }\end{array}$ & $\begin{array}{l}\text { Movements executed are compatible with } \\
\text { both object's specific function on all } 4 \\
\text { trials. }\end{array}$ \\
\hline \multirow[t]{5}{*}{ 5-Automatic motor response ${ }^{a}$} & $\begin{array}{l}\text { Observe for spontaneous automatic motor } \\
\text { behaviours (nose scratching, grasping } \\
\text { bedrail) during the examination. }\end{array}$ & $\begin{array}{l}\text { At least } 2 \text { episodes of automatic motor } \\
\text { behaviour are observed within the } \\
\text { examination. }\end{array}$ \\
\hline & \multicolumn{2}{|l|}{ OR } \\
\hline & $\begin{array}{l}\text { Present a familiar gesture (e.g., wave) and } \\
\text { ask the patient to "Show me how to } \\
\text { wave" } 2 \text { times and "I'm going to wave } \\
\text { again. Do not move at all. Just hold } \\
\text { still" } 2 \text { times. (alternate each command) }\end{array}$ & $\begin{array}{l}\text { Patient performs the gesture on trials } \\
\text { "Just hold still". }\end{array}$ \\
\hline & \multicolumn{2}{|l|}{ OR } \\
\hline & $\begin{array}{l}\text { Place a spoon in front of the patient's } \\
\text { mouth without making contact and ask } \\
\text { the patient to "Show me how to use the } \\
\text { spoon" } 2 \text { times and "I'm going to show } \\
\text { you a spoon. Do not move at all. Just } \\
\text { hold still" } 2 \text { times. (alternate each } \\
\text { command) }\end{array}$ & $\begin{array}{l}\text { Patient performs the gesture on trials } \\
\text { "Just hold still". }\end{array}$ \\
\hline
\end{tabular}


Table 2 continued

\begin{tabular}{|c|c|c|}
\hline Item & Description & Number of observation \\
\hline 4-Object manipulation ${ }^{\mathrm{a}}$ & $\begin{array}{l}\text { Place a ball on the dorsal surface of the } \\
\text { patient's hands and roll the ball across } \\
\text { the index finger and thumb without } \\
\text { touching the surface of the hand or } \\
\text { fingers. Instruct the patient to "Take the } \\
\text { ball". } 4 \text { trials }\end{array}$ & $\begin{array}{l}3 / 4 \text { trial, the wrist must rotate and the } \\
\text { fingers should extend as the object is } \\
\text { moved along the dorsal surface of the } \\
\text { hand; and the object must be grasped } \\
\text { and held for a minimum of } 5 \mathrm{~s} \text {. }\end{array}$ \\
\hline 3-Localization to noxious stimulation ${ }^{\mathrm{a}}$ & $\begin{array}{l}\text { Apply deep pressure to nailbeds of } \\
\text { extremities for a minimum of } 5 \mathrm{~s} .2 \\
\text { trials on each side for a total of } 4 \text { trials. }\end{array}$ & $\begin{array}{l}\text { The non-stimulated limb must locate and } \\
\text { make contact with the stimulated body } \\
\text { part at the point of stimulation on at } \\
\text { least } 2 / 4 \text { trials. }\end{array}$ \\
\hline 2-Flexion withdrawal & $\begin{array}{l}\text { Apply deep pressure to nailbeds of each } \\
\text { extremity. } 1 \text { trial per extremity. }\end{array}$ & $\begin{array}{l}\text { Isolated flexion withdrawal of at least } 1 \\
\text { limb. }\end{array}$ \\
\hline 1-Abnormal posturing & Observe response to above method. & $\begin{array}{l}\text { Slow, stereotyped flexion or extension of } \\
\text { the extremities immediately after the } \\
\text { stimulation. }\end{array}$ \\
\hline 0—None/flaccid & Observe response to above method. & No response to any of the above. \\
\hline \multicolumn{3}{|l|}{ Oromotor/Verbal Function Scale } \\
\hline 3-Intelligible verbalization ${ }^{\mathrm{a}}$ & $\begin{array}{l}\text { Ask the patient to answer } \\
\text { autobiographical or object naming } \\
\text { questions. }\end{array}$ & $\begin{array}{l}\text { Each verbalization must consist of at least } \\
1 \text { consonant-vowel-consonant triad, and } \\
2 \text { different words must be documented, } \\
\text { and words produced by writing or } \\
\text { alphabet board are acceptable. }\end{array}$ \\
\hline 2-Vocalization/oral movement & $\begin{array}{l}\text { Non-reflexive oral movements, } \\
\text { spontaneous vocalizations or } \\
\text { vocalizations that occur during } \\
\text { administration of vocalization } \\
\text { commands. }\end{array}$ & $\begin{array}{l}\text { At least } 1 \text { episode of spontaneous non- } \\
\text { reflexive oral movement and/or } \\
\text { vocalization. (Yawning is scored as } \\
\text { reflexive oral movement) }\end{array}$ \\
\hline 1 -Oral reflexive movement & $\begin{array}{l}\text { Present tongue blade between patient's } \\
\text { lips and/or teeth. }\end{array}$ & $\begin{array}{l}\text { Clamping of jaws, tongue pumping, or } \\
\text { chewing movement. }\end{array}$ \\
\hline 0 - None & Observe response to above method. & No response to any of the above. \\
\hline \multicolumn{3}{|l|}{ Communication scale } \\
\hline 2-Functional: accurate ${ }^{c}$ & $\begin{array}{l}\text { Ask } 6 \text { visual or auditory related questions } \\
\text { (“Am I touching my ear?” “Am I } \\
\text { clapping my hand?”). }\end{array}$ & $\begin{array}{l}\text { Clearly discernible and accurate yes/no } \\
\text { responses on all } 6 \text { of the visual or } \\
\text { auditory related questions. }\end{array}$ \\
\hline 1 -Non-functional: intentional ${ }^{\mathrm{a}}$ & Observe response to above method. & $\begin{array}{l}\text { Clearly discernible and accurate yes/no } \\
\text { responses on at least } 2 / 6 \text { of the visual or } \\
\text { auditory related questions. }\end{array}$ \\
\hline 0 -None & Observe response to above method. & $\begin{array}{l}\text { No discernible verbal or nonverbal } \\
\text { communication. }\end{array}$ \\
\hline \multicolumn{3}{|l|}{ Arousal Scale } \\
\hline 3-Attention & $\begin{array}{l}\text { Consistency of behavioural responses } \\
\text { following verbal or gestural prompts. }\end{array}$ & $\begin{array}{l}\text { No more than } 3 \text { occasions across the } \\
\text { length of the evaluation in which the } \\
\text { patient fails to respond to a verbal } \\
\text { prompt. }\end{array}$ \\
\hline 2-Eye opening w/o stimulation & $\begin{array}{l}\text { Observe status of the eyelids across length } \\
\text { of assessment. }\end{array}$ & $\begin{array}{l}\text { Eyes remain open across the length of the } \\
\text { examination without the need for any } \\
\text { stimulation. }\end{array}$ \\
\hline 1-Eye opening with stimulation & See above. & $\begin{array}{l}\text { Tactile, pressure or noxious stimulation } \\
\text { must be applied at least once during the } \\
\text { examination in order for the patient to } \\
\text { sustain eye opening }\end{array}$ \\
\hline 0-Unarousable & See above. & No eye opening. \\
\hline
\end{tabular}

${ }^{a}$ Denotes a minimally conscious state

b Denotes a minimally conscious state except for anoxic aetiology [70]

${ }^{c}$ Denotes emergence from the minimally conscious state 
activation) [61] and imagine swimming (resulting in supplementary motor area activation) [62].

Concurrently, cheaper and portable techniques using event related potential or electromyography active paradigms have been developed to detect possible signs of command following not assessable by clinical behavioural examination. Schnakers et al. [63] presented a list of names (including their own name) and showed that nine out of 14 studied MCS patients, when instructed to count a target name, showed an increase in amplitude of the P3 potential (known to vary with attention) (none of the eight vegetative/unresponsive patients could do the task). This paradigm also permitted the clinicians to detect consciousness in a rare case of total locked-in syndrome (i.e., characterized by complete immobility including eye movements), behaviourally diagnosed as comatose [43]. Others have adapted this methodology asking patients to count the number of deviant trials in an auditory oddball series [64] (two out of three MCS, one LIS, but none of the four studied vegetative/unresponsive patients could do the task). Finally, Bekinschtein et al. [65] could show subclinical movements by means of electromyography recordings, when patients were asked to move their hand in two out of eight MCS and one vegetative/unresponsive patients (all were traumatic).

Only very recently have such active paradigms being used to communicate with severely brain-damaged patients. Monti and Vanhaudenhuyse et al. [19] were the first to show fMRI based yes/no responses in a patient clinically considered vegetative/unresponsive (i.e., diagnosis on admission; note that subsequent CRS-R testing showed fluctuating behavioural signs of awareness, albeit no capacity to communicate). The patient was asked to answer autobiographical questions by doing motor imagery to answer "yes" and visuo-spatial imagery to answer "no". For five out of six questions, the patient demonstrated reliable fMRI responses and provided correct answers. This methodology was also used by Bardin et al. [62] who observed reliable brain modulation and communication in one out of three MCS patients (albeit obtaining incorrect answers). Note that the one studied locked-in patient failed to do the employed communication paradigm, confirming the major limitations regarding the sensitivity of these fMRI studies.

Table 3 offers an overview of the discussed fMRI, evoked potential and EMG studies aiming to show signs of consciousness and communication not accessible by bedside behavioural examination. The calculated sensitivity [i.e., the proportion of actual (minimally) conscious patients who could do the task] and specificity measures (i.e., the proportion of allegedly unconscious patients who failed to do the task) need to be interpreted with great caution. The absence of functional brain activity in response to the presented instructions can have many possible causes, ranging from test-dependent technological (corrupted signals due to movement or other artefacts often encountered in these patients and especially troublesome in fMRI experiments-e.g., see [66]) to patient-dependent fluctuations in arousal (spontaneous or medication related), perceptual sensory or cognitive insufficiencies (the discussed mental imagery, motor or attentional tasks indeed require preservation of different cognitive processes such as visual, auditory, language and working memory functions). Whilst negative results do not necessarily reflect proof of the absence of consciousness, positive results very likely are informative and relatively easy to interpret as a proof of consciousness.

The neurological community at present has no diagnostic category for patients showing only signs of consciousness or communication on paraclinical fMRI or evoked potential studies such as the ones discussed above $[19,59]$. In the presence of increasingly hard neurophysiologic markers of consciousness [17], the burden of proof for establishing consciousness in severely brain damaged patients no longer exclusively lies in behavioural assessment [67]. Clearly, patients who can "play tennis" and "imagine walking in their house" or use these complex mental imagery tasks to accurately communicate, cannot be considered vegetative/unresponsive or minimally conscious. It could be proposed to call this condition functional locked-in syndrome, emphasising the dissociation between their extreme behavioural motor dysfunction and the identified preserved higher cognitive functions as shown by functional imaging techniques.

What is it like to be minimally conscious or functionally locked-in? Is consciousness in these patients with such severely damaged brains in any ways comparable to our own? Can they experience suffering or satisfaction? Are these lives worth living? These questions are very hard to answer. We cannot ask these non-communicative patients about their self-perceived quality of life. However, we can ask locked-in patients who are also fully dependent on others for their daily life activities and survival. Studies have shown that most chronic locked-in patients selfreported good quality of life, despite their severe restrictions in community reintegration [71]. The longer patients were in a locked-in state, the higher subjective well-being seemed to be. Another recent study showed that invasive mechanical ventilation for locked-in patients who accept tracheotomy allowed life prolongation without affecting quality of life [72]. Medical teams should be aware of that.

In conclusion, some patients who awaken from their coma may fail to show any behavioural sign of awareness (i.e., they are considered to be vegetative or-as we prefer-unresponsive [11]), or they may remain unable to communicate (i.e., are in a minimally conscious state- 


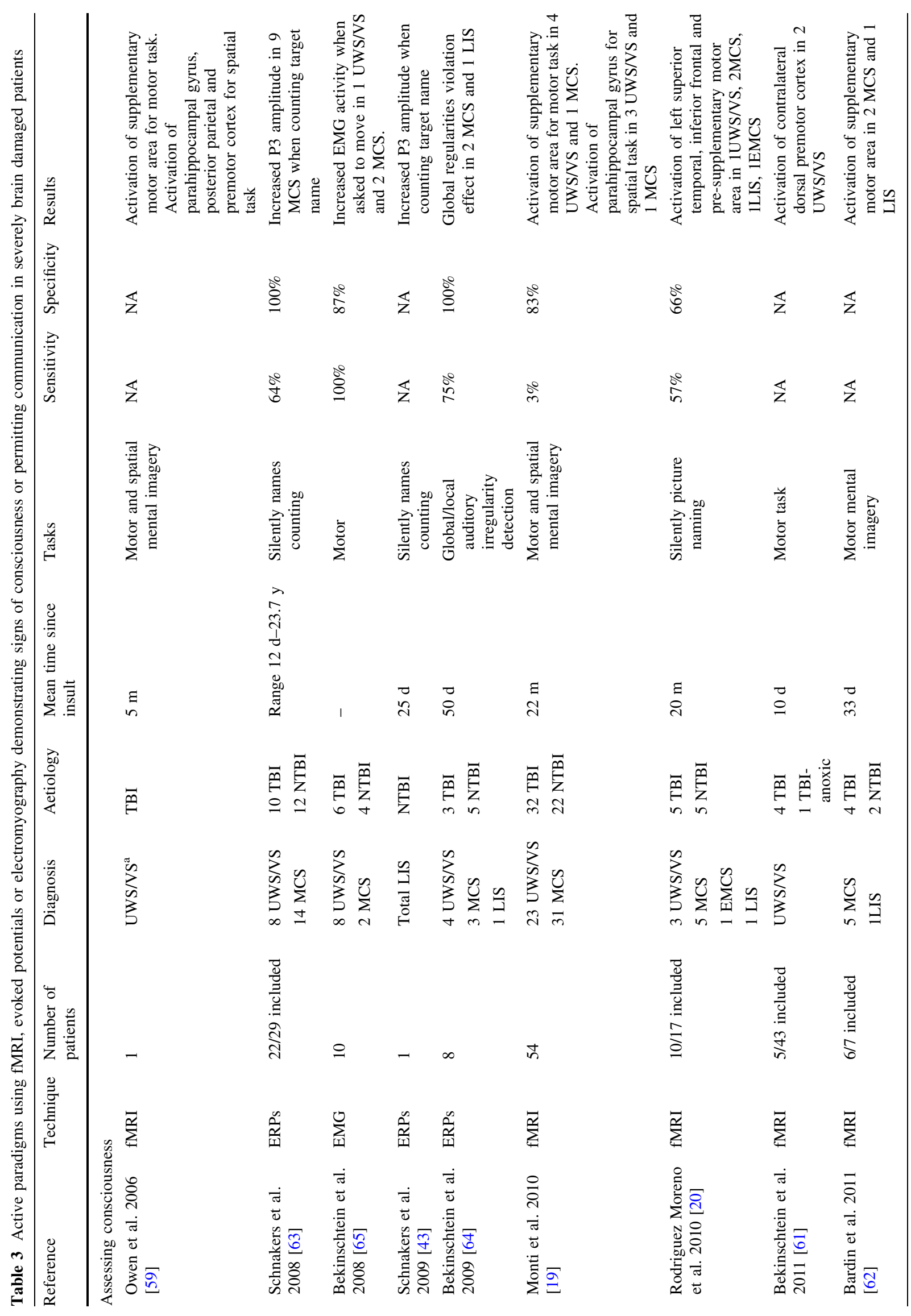




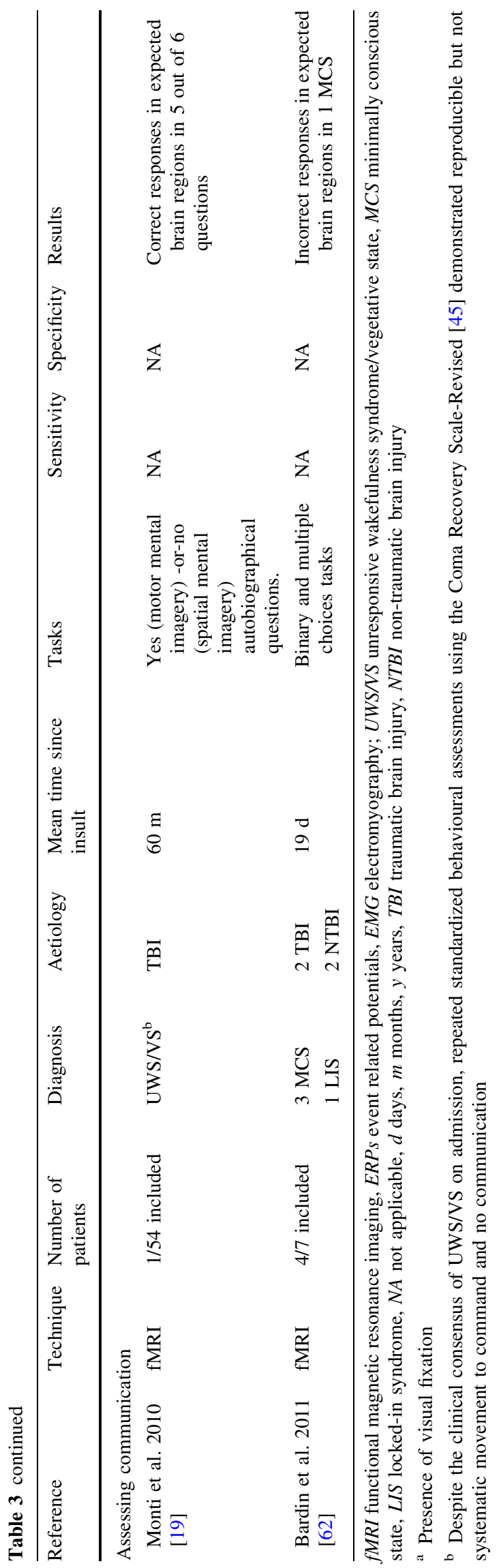

now subdivided into MCS+ (i.e., showing more complex behaviours such as command following) and MCS- (i.e., showing only non-reflex movements). The clinical management of these disorders of consciousness remains very challenging, but technological advances in neuroimaging are now offering new ways to improve our diagnosis. It is an exciting time as the behaviourally defined gray zones between the different disorders of consciousness in the clinical spectrum following coma are being challenged by increasingly powerful imaging technology. For the first time, neurologists may encounter rare but existing cases of functional locked-in syndrome, where only paraclinical tests permit one to demonstrate the presence of higher cognitive function, inaccessible to our motor dependent clinical evaluations. In a not so far future, real-time fMRI based communication [68] or evoked potential brain computer interfaces will be used to address important clinical and ethical questions such as feeling of pain and discomfort [69]. These novel technological means will undoubtedly further improve the existing nosology and clinical care of these challenging patients with disorders of consciousness.

Acknowledgments This study was supported by the Fonds de la Recherche Scientifique (FRS), University and University Hospital of Liège, James S. McDonnell Foundation, Mind Science Foundation, European Commission (Mindbridge, DISCOS, DECODER \& COST) and Belgian French-Speaking Community Concerted Research Action. AV is Postdoctoral Fellows at FRS. MAB is Research Fellow at FRS. SL is Senior Research Associate at FRS.

Conflict of interest The authors declare that they have no competing interests.

\section{References}

1. Demertzi A, Ledoux D, Bruno MA, Vanhaudenhuyse A, Gosseries O, Soddu A, Schnakers C, Moonen G, Laureys S (2011) Attitudes towards end-of-life issues in disorders of consciousness: a European survey. J Neurol 258(6):1058-1065

2. Luchetti M (2010) Eluana Englaro, chronicle of a death foretold: ethical considerations on the recent right-to-die case in Italy. J Med Ethics 36:333-335

3. Laureys S (2005) Science and society: death, unconsciousness and the brain. Nat Rev Neurosci 6:899-909

4. Laureys S, Pellas F, Van Eeckhout P, Ghorbel S, Schnakers C, Perrin F, Berre J, Faymonville ME, Pantke KH, Damas F, Lamy M, Moonen G, Goldman S (2005) The locked-in syndrome: what is it like to be conscious but paralyzed and voiceless? Prog Brain Res 150:495-511

5. Jennett B (2005) Thirty years of the vegetative state: clinical, ethical and legal problems. Prog Brain Res 150:537-543

6. The Multi-Society Task Force on PVS (1994) Medical aspects of the persistent vegetative state (1). N Engl J Med 330:1499-1508

7. Estraneo A, Moretta P, Loreto V, Lanzillo B, Santoro L, Trojano L (2010) Late recovery after traumatic, anoxic, or hemorrhagic long-lasting vegetative state. Neurology 75:239-245 
8. Solarino B, Bruno F, Frati G, Dell'erba A, Frati P (2011) A national survey of Italian physicians' attitudes towards end-of-life decisions following the death of Eluana Englaro. Intensive Care Med 37:542-549

9. Giacino JT, Ashwal S, Childs N, Cranford R, Jennett B, Katz DI, Kelly JP, Rosenberg JH, Whyte J, Zafonte RD, Zasler ND (2002) The minimally conscious state: definition and diagnostic criteria. Neurology 58:349-353

10. Shewmon DA (2004) A critical analysis of conceptual domains of the vegetative state: sorting fact from fancy. NeuroRehabilitation 19:343-347

11. Laureys S, Celesia GG, Cohadon F, Lavrijsen J, Leon-Carrion J, Sannita WG, Sazbon L, Schmutzhard E, von Wild KR, Zeman A, Dolce G (2010) Unresponsive wakefulness syndrome: a new name for the vegetative state or apallic syndrome. BMC Med $8: 68$

12. Tavalaro J, Tayson R (1997) Look up for yes. Kodansha America, Inc, New York

13. Borthwick C (1995) The proof of the vegetable: a commentary on medical futility. J Med Ethics 21:205-208

14. Velez GJ (2005) Death of John Paul II and the basic human care for the sick and the dying. Ethics Med 21:167-177

15. Racine E, Amaram R, Seidler M, Karczewska M, Illes J (2008) Media coverage of the persistent vegetative state and end-of-life decision-making. Neurology 71:1027-1032

16. Owen AM, Schiff ND, Laureys S (2009) A new era of coma and consciousness science. Prog Brain Res 177:399-411

17. Laureys S, Boly M (2008) The changing spectrum of coma. Nat Clin Pract Neurol 4:544-546

18. Schnakers C, Vanhaudenhuyse A, Giacino J, Ventura M, Boly M, Majerus S, Moonen G, Laureys S (2009) Diagnostic accuracy of the vegetative and minimally conscious state: clinical consensus versus standardized neurobehavioral assessment. BMC Neurol 9:35

19. Monti MM, Vanhaudenhuyse A, Coleman MR, Boly M, Pickard JD, Tshibanda L, Owen AM, Laureys S (2010) Willful modulation of brain activity in disorders of consciousness. N Engl J Med 362:579-589

20. Rodriguez Moreno D, Schiff ND, Giacino J, Kalmar K, Hirsch J (2010) A network approach to assessing cognition in disorders of consciousness. Neurology 75:1871-1878

21. Laureys S, Boly M, Maquet P (2006) Tracking the recovery of consciousness from coma. J Clin Invest 116:1823-1825

22. Voss HU, Uluc AM, Dyke JP, Watts R, Kobylarz EJ, McCandliss BD, Heier LA, Beattie BJ, Hamacher KA, Vallabhajosula S, Goldsmith SJ, Ballon D, Giacino JT, Schiff ND (2006) Possible axonal regrowth in late recovery from the minimally conscious state. J Clin Invest 116:2005-2011

23. Monti MM, Laureys S, Owen AM (2010) The vegetative state. Bmj 341:292-296

24. Bruno MA, Gosseries O, Ledoux D, Hustinx R, Laureys S (2011) Assessment of consciousness with electrophysiological and neurological imaging techniques. Curr Opin Crit Care 17:146-151

25. Boly M, Faymonville ME, Schnakers C, Peigneux P, Lambermont B, Phillips C, Lancellotti P, Luxen A, Lamy M, Moonen G, Maquet P, Laureys S (2008) Perception of pain in the minimally conscious state with PET activation: an observational study. Lancet Neurol 7:1013-1020

26. Vanhaudenhuyse A, Noirhomme Q, Tshibanda LJ, Bruno MA, Boveroux P, Schnakers C, Soddu A, Perlbarg V, Ledoux D, Brichant JF, Moonen G, Maquet P, Greicius MD, Laureys S, Boly M (2010) Default network connectivity reflects the level of consciousness in non-communicative brain-damaged patients. Brain 133:161-171

27. Coleman MR, Davis MH, Rodd JM, Robson T, Ali A, Owen AM, Pickard JD (2009) Towards the routine use of brain imaging to aid the clinical diagnosis of disorders of consciousness. Brain 132:2541-2552

28. Luaute J, Maucort-Boulch D, Tell L, Quelard F, Sarraf T, Iwaz J, Boisson D, Fischer C (2010) Long-term outcomes of chronic minimally conscious and vegetative states. Neurology 75:246252

29. Dolce G, Quintieri M, Serra S, Lagani V, Pignolo L (2008) Clinical signs and early prognosis in vegetative state: a decisional tree, data-mining study. Brain Inj 22:617-623

30. Gosseries O, Bruno MA, Chatelle C, Vanhaudenhuyse A, Schnakers C, Soddu A, Laureys S (2011) Disorders of consciousness: what's in a name? NeuroRehabilitation 28:3-14

31. Bruno M-A, Schnakers C, Boly M, Hustinx R, Vanhaudenhuyse A, Kirsch M, Bernard C, Moonen G, Laureys S (2009) Subcategorizing the minimally conscious state based on cerebral metabolism PET studies [abstract]. In: 19th Meeting of the European Neurological Society. Milan, Italy

32. Demertzi A, Vanhaudenhuyse A, Bruno MA, Schnakers C, Boly M, Boveroux P, Maquet P, Moonen G, Laureys S (2008) Is there anybody in there? Detecting awareness in disorders of consciousness. Expert Rev Neurother 8:1719-1730

33. Laureys $S$ (2005) The neural correlate of (un)awareness: lessons from the vegetative state. Trends Cogn Sci 9:556-559

34. Vanhaudenhuyse A, Demertzi A, Schabus M, Noirhomme Q, Bredart S, Boly M, Phillips C, Soddu A, Luxen A, Moonen G, Laureys S (2010) Two distinct neuronal networks mediate the awareness of environment and of self. J Cogn Neurosci 23:570-578

35. Majerus S, Bruno MA, Schnakers C, Giacino JT, Laureys S (2009) The problem of aphasia in the assessment of consciousness in brain-damaged patients. Prog Brain Res 177:49-61

36. Bruno M-A, Fernández-Espejo D, Lehembre R, Tshibanda L, Vanhaudenhuyse A, Gosseries O, Lommers E, Noirhomme Q, Boly M, Napolitani M, Owen AM, Laureys S, Soddu A (2010) Multi-modal imaging in left hemisphere damaged patients with disorders of consciousness. Prog Brain Res (in press)

37. Bruno M, Schnakers C, Damas F, Pellas F, Lutte I, Bernheim J, Majerus S, Moonen G, Goldman S, Laureys S (2009) Locked-in syndrome in children: report of five cases and review of the literature. Pediatr Neurol 41:237-246

38. Smart CM, Giacino JT, Cullen T, Moreno DR, Hirsch J, Schiff ND, Gizzi M (2008) A case of locked-in syndrome complicated by central deafness. Nat Clin Pract Neurol 4:448-453

39. Seel RT, Sherer M, Whyte J, Katz DI, Giacino JT, Rosenbaum AM, Hammond FM, Kalmar K, Pape TL, Zafonte R, Biester RC, Kaelin D, Kean J, Zasler N (2010) Assessment scales for disorders of consciousness: evidence-based recommendations for clinical practice and research. Arch Phys Med Rehabil 91:1795-1813

40. Jennett B, Bond M (1975) Assessment of outcome after severe brain damage. Lancet 1:480-484

41. Rankin J (1957) Cerebral vascular accidents in patients over the age of 60. II. Prognosis. Scott Med J 2:200-215

42. Bruno MA, Ledoux D, Lambermont B, Damas F, Schnakers C, Vanhaudenhuyse A, Gosseries O, Laureys S (2011) Comparison of the full outline of unresponsiveness and Glasgow Liege Scale/ Glasgow Coma Scale in an intensive care unit population. Neurocrit Care [Epub ahead of print]

43. Schnakers C, Perrin F, Schabus M, Hustinx R, Majerus S, Moonen G, Boly M, Vanhaudenhuyse A, Bruno MA, Laureys S (2009) Detecting consciousness in a total locked-in syndrome: An active event-related paradigm. Neurocase 15(4):271-277

44. Schnakers C, Giacino J, Kalmar K, Piret S, Lopez E, Boly M, Malone R, Laureys S (2006) Does the FOUR score correctly diagnose the vegetative and minimally conscious states? Ann Neurol 60:744-745 
45. Giacino JT, Kalmar K, Whyte J (2004) The JFK Coma Recovery Scale-Revised: measurement characteristics and diagnostic utility. Arch Phys Med Rehabil 85:2020-2029

46. Rader MA, Ellis DW (1994) The Sensory Stimulation Assessment Measure (SSAM): a tool for early evaluation of severely brain-injured patients. Brain Inj 8:309-321

47. Shiel A, Horn SA, Wilson BA, Watson MJ, Campbell MJ, McLellan DL (2000) The Wessex Head Injury Matrix (WHIM) main scale: a preliminary report on a scale to assess and monitor patient recovery after severe head injury. Clin Rehabil $14: 408-416$

48. Ansell BJ, Keenan JE (1989) The western neuro sensory stimulation profile: a tool for assessing slow-to-recover head-injured patients. Arch Phys Med Rehabil 70:104-108

49. Gill-Thwaites H (1997) The sensory modality assessment rehabilitation technique - a tool for assessment and treatment of patients with severe brain injury in a vegetative state. Brain Inj 11:723-734

50. Pape TL, Senno RG, Guernon A, Kelly JP (2005) A measure of neurobehavioral functioning after coma. Part II: Clinical and scientific implementation. J Rehabil Res Dev 42:19-28

51. Rappaport M, Dougherty AM, Kelting DL (1992) Evaluation of coma and vegetative states. Arch Phys Med Rehabil 73:628-634

52. Wijdicks EF, Bamlet WR, Maramattom BV, Manno EM, McClelland RL (2005) Validation of a new coma scale: the FOUR score. Ann Neurol 58:585-593

53. Stanczak DE, White JG 3rd, Gouview WD, Moehle KA, Daniel M, Novack T, Long CJ (1984) Assessment of level of consciousness following severe neurological insult. A comparison of the psychometric qualities of the Glasgow Coma Scale and the Comprehensive Level of Consciousness Scale. J Neurosurg 60:955-960

54. Benzer A, Mitterschiffthaler G, Marosi M, Luef G, Puhringer F, De La Renotiere K, Lehner H, Schmutzhard E (1991) Prediction of non-survival after trauma: Innsbruck Coma Scale. Lancet 338:977-978

55. Born JD, Albert A, Hans P, Bonnal J (1985) Relative prognostic value of best motor response and brain stem reflexes in patients with severe head injury. Neurosurgery 16:595-601

56. Borer-Alafi N, Gil M, Sazbon L, Korn C (2002) Loewenstein communication scale for the minimally responsive patient. Brain Inj 16:593-609

57. Stalhammar D, Starmark JE, Holmgren E, Eriksson N, Nordstrom CH, Fedders O, Rosander B (1988) Assessment of responsiveness in acute cerebral disorders. A multicentre study on the reaction level scale (RLS 85). Acta Neurochir (Wien) 90:73-80

58. Laureys S, Owen AM, Schiff ND (2004) Brain function in coma, vegetative state, and related disorders. Lancet Neurol 3:537-546

59. Owen AM, Coleman MR, Boly M, Davis MH, Laureys S, Pickard JD (2006) Detecting awareness in the vegetative state. Science 313:1402
60. Boly M, Coleman MR, Davis MH, Hampshire A, Bor D, Moonen G, Maquet PA, Pickard JD, Laureys S, Owen AM (2007) When thoughts become action: an fMRI paradigm to study volitional brain activity in non-communicative brain injured patients. Neuroimage 36:979-992

61. Bekinschtein TA, Manes FF, Villarreal M, Owen AM, Della Maggiore V (2011) Functional imaging reveals movement preparatory activity in the vegetative state. Front Hum Neurosci 5:5

62. Bardin JC, Fins JJ, Katz DI, Hersh J, Heier LA, Tabelow K, Dyke JP, Ballon DJ, Schiff ND, Voss HU (2011) Dissociations between behavioural and functional magnetic resonance imaging-based evaluations of cognitive function after brain injury. Brain 134:769-782

63. Schnakers C, Perrin F, Schabus M, Majerus S, Ledoux D, Damas P, Boly M, Vanhaudenhuyse A, Bruno MA, Moonen G, Laureys S (2008) Voluntary brain processing in disorders of consciousness. Neurology 71(20):1614-1620

64. Bekinschtein TA, Dehaene S, Rohaut B, Tadel F, Cohen L, Naccache L (2009) Neural signature of the conscious processing of auditory regularities. Proc Natl Acad Sci USA 106:1672-1677

65. Bekinschtein TA, Coleman MR, Niklison J 3rd, Pickard JD, Manes FF (2008) Can electromyography objectively detect voluntary movement in disorders of consciousness? J Neurol Neurosurg Psychiatry 79:826-828

66. Soddu A, Vanhaudenhuyse A, Bahri MA, Bruno MA, Boly M, Demertzi A, Tshibanda JF, Phillips C, Stanziano M, Ovadia-Caro S, Nir Y, Maquet P, Papa M, Malach R, Laureys S, Noirhomme Q (2011) Identifying the default-mode component in spatial IC analyses of patients with disorders of consciousness. Hum Brain Mapp. doi: $10.1002 / \mathrm{hbm} .21249$

67. Giacino JT, Schnakers C, Rodriguez-Moreno D, Kalmar K, Schiff N, Hirsch J (2009) Behavioral assessment in patients with disorders of consciousness: gold standard or fool's gold? Prog Brain Res 177:33-48

68. Sorger B, Dahmen B, Reithler J, Gosseries O, Maudoux A, Laureys S, Goebel R (2009) Another kind of 'BOLD Response': answering multiple-choice questions via online decoded singletrial brain signals. Prog Brain Res 177:275-292

69. Laureys S, Boly M (2007) What is it like to be vegetative or minimally conscious? Curr Opin Neurol 20:609-613

70. Bruno M-A, Vanhaudenhuyse A, Schnakers C, Boly M, Gosseries O, Demertzi A, Majerus S, Moonen G, Hustinx R, Laureys S (2010) Visual fixation in the vegetative state: an observational case series PET study. BMC Neurol 10:35

71. Bruno M-A, Bernheim J, Ledoux D, Pellas F, Demertzi A, Laureys $S$ (2011) A survey on self-assessed wellbeing in a cohort of chronic locked-in syndrome patients: happy majority, miserable minority. BMJ Open, Published Online First 23 February 2011

72. Rousseau MC, Pietra S, Blaya J, Catala A (2011) Quality of life of ALS and LIS patients with and without invasive mechanical ventilation. J Neurol, Published Online First Apr 22011 